DOI https://doi.org/10.18551/rjoas.2018-01.11

\title{
EFFECT OF MONETARY VARIABLES ON CONVENTIONAL BANK PERFORMANCE AND SHARIA BANKS IN INDONESIA, 2010-2017
}

\author{
Akbar Ali*, Amir Amri, Delis Arman, Machudin Asep \\ Jambi University, Indonesia \\ *E-mail: ali.akbar7320@gmail.com
}

\begin{abstract}
The purpose of this study to determine the influence of monetary, interest rate, rupiah exchange rate and money supply on conventional bank performance and performance of Sharia bank. Population in this research is all conventional banking and all Sharia banking in Indonesia for 2010-2017. The sample is conventional bank as much as 14 banks, and Sharia bank as much as 6 banks with time series data of 30 . The method used is Partial Least Square Analysis. The results showed that the interest rate has no significant effect on the performance of conventional banks and Sharia banks. The exchange rate has a significant and positive effect on the performance of both conventional and Sharia banks. While the variable amount of money in circulation has a negative and real effect on the performance of conventional banks and Sharia.
\end{abstract}

\section{KEY WORDS}

Interest rate, exchange rate, total money supply, bank performance.

Monetary policy (kebijakan moneter) is all the efforts or actions of the Central Bank in affect the development of monetary variables (money supply, interest rates, credit and exchange rate) to achieve certain economic goals (Litteboy and Taylor, 2006: 198; Mishkin, 2004: 457).

Monetary policy is to control or direct the macro economy to the desired (better) condition by regulating the money supply. While the meaning of better conditions is to increase the output, balance and / or maintaining price stability (controlled inflation). Through monetary policy the government can maintain, increase or decrease the money supply in an effort to maintain the ability of the economy still grow while controlling inflation (Rahardja and Manurung, 2008:256).

According to Nopirin (2000: 45), monetary policy is an action by the monetary authorities (usually the central bank) to influence the money supply and credit which in turn that will affect the economic activities of the community.

Theoretically there are two main lines of monetary policy transmission mechanism, namely through the money supply and the price line through interest rates. This rate of interest is important to the Indonesian economy. With monetary policy, the Central Bank (Bank Indonesia) can control the money supply and banking system.

In particular monetary policy can be interpreted as a macro action by influencing the process of making / printing money. The process of making / printing money can be affect the money supply so that it can affect the interest rate applicable in the money market, investment spending (I), aggregate demand (AD), price level $(P)$ and output.

In its implementation, monetary policy can be expansionary (monetary policy), which is monetary policy through increasing money supply (MS) and / or interest rate reduction (i) in order to increase aggregate demand in economy and contractionary monetary policy) is monetary policy through reduction of money supply (MS) and or interest rate increase (i) with the aim of reducing aggregate demand in the economy.

Monetary targets or more, especially the control of the money supply is a pure monetary policy that is not accompanied by changes in the value of government spending, taxes and government transfers (Soediyono, 1994).

In monetary policy, the government can also control the money supply, credit and banking system (Nanga, 2005: 180). 
According Mankiw (2007), external factors that affect the performance of banks is a macroeconomic condition. The macroeconomic conditions affecting the bank's performance are inflation, interest rates, and the exchange rate in an economy. These external factors are described as follows: Inflation; Interest Rate (SBI); Currency Exchange.

Macroeconomics is external factors consisting of events that come from outside the company, so that the company can not to control it (Djamil, 1989). According to Athanasoglou et al. (2006) states that bank profitability is influenced by internal and external factors. Further Athanasoglou (2006) explains that external factors are unrelated to bank management, but have an indirect impact on the economy and financial institutions.

\section{METHODS OF RESEARCH}

Influence of Interest Rate on CAR, NPL / NPF, ROA and LDR / FDR. The reference rate (BI Rate) is a variable affecting the level of bank liquidity in Indonesia. In accordance with Keynes's theory of liquidity preference, the benchmark of interest rate will affect the balance between demand and supply of money. Thus, monetary policy will affect the nominal interest rate in the money market (Mankiw, 2009). BI Rate as moderating variable to CAR, before it has absorbed determinant factors influencing it, there are currency exchange rate (exchange rate, external impact reflect), net export-import, money supply (M0, monetary base; M1). According to Sesy Rizkiyanti Oktavia (2010: 94), BI Rate has a positive and significant influence on CAR. This means that if an increase in the BI Rate, then the amount of CAR will also rise, and vice versa.

According Dwihandayani (2013, h.10). the relationship between the BI Rate and the NPL indicates a positive influence so that the greater the BI Rate, the greater the credit / NPL risk.

Naturally that all banks in Indonesia are obedient and obedient to Bank Indonesia (BI) which acts as a central bank with monetary authority, banking and state payment system. Bank Indonesia has a duty to maintain monetary stability among others through interest rate instruments in open market operations. Monetary policy through the implementation of interest rates are too tight, that will tend to be deadly economic activity. Vice versa, the increase in $\mathrm{BI}$ Rate has resulted in tight banking liquidity, so that banks have difficulty to obtain low-cost funds from third parties (demand deposits, savings deposits, deposits). This resulted in the cost of funds in the bank will increased / high. As a result, when there is a high increase in loan interest, the value of the customer's business is no longer comparable with the financing provided. If the customer has already started to object to a high interest rate then it will raise the possibility of bad credit. This theory is supported by Oktavia (2009) which states interest rates have a positive effect on ROA.

In the research conducted, Budi Asih suggested that the interest rate is used as one of monetary policy by Bank Indonesia to regulate the circulation of money. If the circulation of money is considered too much, then $\mathrm{Bl}$ will increase interest rate certificates of Bank Indonesia and vice versa if the circulation of money is too little then Bank Indonesia will degrade interest rates. With the increase in the BI Rate will lead to increase the interest rates on deposits and credit. Thus will affect the Loan to Deposit Ratio / LDR (Bank Indonesia, 2010). The above is in line with the research of Devi Puspitasari (2010) where the BI Rate is used as a reference in monetary operation which is expected to affect the money market interest rate, deposit interest rate and long-term interest rate which will affect the people's desire to deposit or withdraw their funds in the bank.

Effect of Exchange Rates on CAR, NPL / NPF, ROA and LDR / FDR. The existence of foreign exchange has been used not only as a commodity in the money market, but also in export and import trade. When people want to buy goods sold in foreign currencies, especially the dollar, then people will exchange their money to banks and bank mediators such as money changer to get a dollar to buy the goods. This makes the circulation of rupiah in the community will go into the bank and become a source of funds that determine the liquid or not the bank. This is in accordance with the one proposed by Sukirno (2008: 397) where the exchange rate as the amount of domestic money required, amount of rupiah 
required to obtain a unit of foreign currency. If the people need a lot of foreign money then the domestic currency will be much exchanged through the bank and will have an impact on bank liquidity.

Influence of Money Supply on CAR, NPL / NPF, ROA and LDR / FDR. The money supply in the broadest sense (M2) is the total amount of money officially issued by the central bank in the form of currency, or demand deposit and quasi money (savings, foreign currency, deposits) in the banking system (M1) plus the circulation of money in the market finance (Palley, 2014; Levagne, et all, 2014; Kyung, 2008; Siok, 2009). M2 macro variables will transmit to bank liquidity through third party customer funds (M1), value of securities assets, interbank transactions and cash opinions from depository services, settlement and storage of financial market transactions.

Approach Method. The population used in this study is the existing commercial banks (registered) at Bank Indonesia period 2010-2015. Based on the Indonesian Banking Statistics Indonesia (SPI) in June 2017 published by the Financial Services Authority and accessible through the website www.ojk.go.id on the menu Data and Statistics-Banking, where the number of commercial banks (conventional commercial banks and Sharia commercial banks) as much 115 (one hundred and fifteen) banks consisting of 102 conventional banks and 13 Sharia banks (4 state banks, 42 national private foreign exchange banks (BUSN foreign exchange), 21 national private non-foreign exchange commercial banks (BUSN Non Foreign Exchange), 27 development banks regional (BPD), 12 mixed banks and 9 foreign banks).

The sample is part of the object under study, (Umi Narimawati (2010: 38) states the sample is a portion of the population selected to be the observation unit in the study. Thus the sample is part of the population to be studied. Of the 115 (one hundred and fifteen) general banking population (103 conventional banks and 12 Sharia banks), the samples used / taken are 20 (twenty) commercial banks (14 conventional banks and 6 Sharia banks), with a total sample size $(20 \times 30=600$ samples $)$. The sample selection criteria are as follows:

- Conventional Banks and Sharia Banks registered at Bank Indonesia and still operating during the period of study (2010 - 2016).

- The financial statements of the Bank under study (period 2010 - 2016) are available in full at both Bank Indonesia (BI), the Financial Services Authority (OJK) and the respective Bank's official website. In this research the type of data used is secondary data in the form of monetary report (interest rate, exchange rate and money supply) and quarterly financial report of Conventional Bank and Sharia Bank in Indonesia period 2010 - June 2017 and other data available in Bank Indonesia $\mathrm{BI}$ ) and the Financial Services Authority (OJK) and other official sources supporting this research.

The secondary data is sourced from Bank Indonesia $(\mathrm{BI})$, the Financial Services Authority (OJK), the official website of each Bank which is sampled, the literature and the previous research results that are related and related to this research. Methods of data collection in this study are:

- The method of observation is by direct observation of the Monetary Report (interest rate, exchange rate, and money supply) and Annual Financial Report on 20 (twenty) banks which become the sample of this study (14 conventional banks and 6 syariah banks) 2010 period - June 2017.

- Library research method (library research) is by studying and reviewing the various literature-related literature that will be studied.

In this study, researchers used descriptive analysis method and Quantitative Descriptive, namely:

- Inferential descriptive namely: a method to analyze monetary and financial data by means of inductive statistical analysis.

- Descriptive Qualitative namely: a method used to analyze the existing monetary and financial data by applying theory or concept to facts.

In the research, the data obtained and the proposed hypotheses will be analyzed and tested by means of analysis / statistical test of variance based structural equation or 
Structural Equation Modeling (SEM) - Partial Least Square (PLS) using Smart PLS software program. The consideration of using SEM-PLS model, because of its ability to measure construct through its indicators, analyzing indicator variable, latent variable, and error of measurement and can do direct analysis (not one by one diregresi) relationship between independent variable (independent variable / exogenous) with dependent variable (dependent variable / endogenous).

According to Imam Ghozali (2006: 18), Partial Least Square (PLS) is a powerful analytical method because it does not assume data to be measured by a certain scale, the number of small samples. The purpose of Partial Least Square (PLS) is to help researchers to get the value of latent variables for prediction purposes.

\section{RESULTS AND DISCUSSION}

Effect of Interest Rates on Conventional Bank Performance and Sharia Bank. The hypothesis of monetary variables (interest rate, exchange rate, and money supply in partial and simultaneous) simultaneously affect the internal variables (credit policy and Conventional Bank operational policy). According to result of hypothesis test known that external factor have not significant effect to performance of ank proved with value of $P$ Value equal to 0,302 bigger than 0,05 and coefficient value 0,885 . This means that external factor variables consisting of indicators: interest rate, exchange rate, and money supply have no effect on bank performance as measured by CAR, MPL, ROA and LDR indicators. The results of this study Kamalia Octaviyanti, Sunu Priyawan and Tri Ratnawati (2013) in their research have founded that external factors using inflation indicators, SBI rates, and exchange rates significantly influence the performance of banks as measured by Return On Assets (ROA) and Return On Equity (ROE) and supports the results of research by Diyanti and Widyarti (2012) who found that external factors measured using inflation variables significantly influence bank performance, also support the results of Angrish (2010) study which states that macroeconomic variables other than GDP significantly explain the performance of banking. Furthermore, this result also supports the findings of Sitorus (2004) and Dermiguc-Kunt and Huizinga (1997 and 2001) who found that external factors such as inflation, SBI rates, and exchange rates (exchange rate) have a significant effect on bank performance. However, this result does not support Setiawan's research (2009) which found that external factors of inflation did not significantly affect bank performance as measured by ROA ratio. This difference of findings is possible because the observation period used in the study is in relatively stable condition where only in 2008 the banking industry in Indonesia experienced a slight shake due to subprime mortgage that occurred in the United States and not too use the financial cycle of the banking industry in Indonesia.

The Effect of Currency Exchange (Exchange Rate) on Conventional Bank Performance and Sharia Bank. The exchange rate is the price at which a country's currency can be converted into a currency of another country. The exchange rate of a currency affects the economy if the currency exchange rate depreciates. Fluctuations in exchange rate changes are the focus of the foreign currency market. The fluctuations in this currency will affect the amount of credit extended.

Tests in this study showed that the exchange rate has a positive effect on the total credit (financing). The results of this test show that the greater the exchange rate the greater the total credit. Based on the hypothesis test, it is known that exchange rate has no significant effect to operational policy and to bank performance as evidenced by $\mathrm{P}$ value 0,172 bigger than 0,05 and coefficient value of path to internal variable equal to 0,85 and from conventional internal variable to total credit of 0.828 . This means that external exchange rate variables do not affect the internal variables of Conventional Banks, and when associated with bank performance as measured by CAR, NPL, ROA and LDR indicators are low.

These results are in accordance with the hypothesis formulated and support the results of Sukarno and Syaichu (2006), Setiawan (2009), and Olajide, Asaolu and Jegede (2011) studies that found that internal factors measured using CAR and LDR ratios have a positive 
and significant impact on bank performance measured using ROA. The results explain that the better performance of internal factors of the bank, it will encourage the performance of banks in general in reaching the level of profitability for the better.

The results of Dinnul, et al (2017) obtained the result that exchange rate variable has no effect on bank performance (ROA). The results showed that the exchange rate variable against ROA, from the coffuicient table obtained $t_{\text {count }}$ of -0.089 which means $t_{\text {count }}<t_{\text {table }}(-$ $0.089<1.66023)$ which shows the variable of inflation has a negative effect and and the value of sig $t=0.929$ which means sig $t>\alpha(0.929>0.05)$. Therefore, $H_{0}$ is accepted and $\mathrm{H \alpha}$ is rejected meaning partially there is no influence between Exchange Rate to ROA. Capital Adequacy Ratio (CAR) no significant influence on Return On Assets (ROA). This condition can reflect that the greater the CAR, the higher the bank's capital capacity in maintaining the possibility. The risks arising from loss of business activities but not necessarily significantly affect the ROA. On the other hand, high CAR can reduce the ability of banks in expanding their business because the greater the capital reserves used to cover the risk of loss. Inhibition of business expansion due to high CAR which will ultimately affect the financial performance of the bank. Results of supportive research conducted by Tan Sau Eng (2013) and Julita (2015). The test result of Exchange Rate or exchange rate has no effect on Return On Asset (ROA). In theory, the exchange rate or exchange rate must significantly affect the ROA of Sharia Banking, since the exchange rate will determine the return on real investment. A declining currency will clearly reduce the purchasing power of revenues and capital gains derived from any type of investment. This decrease in investment will affect the bank's operational activities. With the decline in investment, the demand for Islamic financing will also decline and will further affect the financial ratios of banks. Results research supported by Putri Asrina (2015) and Mariana (2015).

The theory that reveals how the exchange rate is determined is the purchasing power parity (PPP) theory. This theory states that the exchange rate between two currencies will make adjustments that reflect changes in the price level of both countries (Miskhin, 2008). Warjiyo, Perry, and Solikin (2003) in his monetary policy in Indonesia suggested that the exchange rate transmission mechanism emphasizes that exchange rate movements can affect the development of aggregate supply and demand, and further output and prices.

According to Umie Wulaningsih (2012) the size of the influence of exchange rate movements depends on the floating exchange rate system of expansive monetary policy by the Central Bank will encourage the depreciation of domestic currency and increase the price of imported goods. This will further boost domestic goods prices, although there is no expansion on the aggregate demand side. Then rising prices will have an impact on rising inflation, rising inflation will basically affect the interest rate. According Darmawi (2003) interest rate risk is one of the risks affecting the ATMR, so if the interest rate increases then the ATMR is inversely proportional. Research conducted Samson, Harley, and Amerah (2012) shows the exchange rate has a negative influence on the CAR.

Influence of Money Supply on Conventional Bank Performance and Sharia Bank. The money supply in the broadest sense of the total amount of money officially issued by the central bank in the form of currency, demand deposit, and quasi money (savings, taro, deposits). This money supply represents the money supply which is the money circulating in the community. The results showed that the large amount of money in circulation has a significant effect on credit financing as evidenced by $\mathrm{P}$ - value of 0.000 which is smaller than 0.01 and the coefficient value of 0.784 . This means that the external factor variable of money supply has a very significant effect on Total Credit (financing). This means that the high amount of outstanding amount is very significantly determined by the amount of credit (financing). The results of this study are in line with Maharani Ika Lestari (2007) that the money supply has a positive effect on Total Credit and Sesy RO (2010) that the money supply has an effect on Capital Adequacy Ratio (CAR) and its implication on working capital credit is very significant. 


\section{CONCLUSION}

The results showed that the interest rate monetary factor has no significant effect on the performance of ank as evidenced by the value of $P$ Value of 0.302 which is greater than 0.05 and the coefficient value of 0.885 lanes. This means that the monetary factor variable consisting of indicators: interest rates do not affect the performance of banks as measured by indicators CAR, MPL, ROA, and LDR. The monetary factor of the exchange rate has a positive and significant effect on the performance of conventional banks and Sharia banks as evidenced by the value of $P$ value of 0.172 which is greater than 0.05 and the coefficient value of the path to internal variables of 0.85 and from conventional internal variables to total credits of 0.828 . This means that external exchange rate variables do not affect the internal variables of Conventional Banks, and when associated with bank performance as measured by CAR, NPL, ROA and LDR indicators are low. The monetary factor with the indicator of the amount of money in circulation has a significant effect on credit financing as evidenced by the $P$ - value of 0.000 which is smaller than 0.01 and the path coefficient value of 0.784 . This means that the external factor variable of money supply has a very significant effect on Total Credit (financing). This means that the high amount of outstanding amount is very significantly determined by the amount of credit (financing). The results of this study are in line with Maharani Ika Lestari (2007) that the money supply has a positive effect on Total Credit and Sesy RO (2010) that the money supply has an effect on Capital Adequacy Ratio $(C A R)$ and its implication on working capital credit is very significant.

\section{REFERENCES}

1. Angrish, D. 2010. Can Macroeconomic Fundamentals Predict The Performance of Commercial Banks. A Thesis. Faculty of the University of Georgia.

2. Bank Indonesia. 2002. Cetak Biru Pengembangan Perbankan Syariah Indonesia. Jakarta.

3. Devi Puspitasari. 2010. Pengaruh DPK, NPL, Inflasi dan BI Rate Terhadap LDR Pada Bank Umum di Indonesia Periode 2007-2011. Tesis. Program Studi Magister Akuntansi. Universitas Pasundan.

4. Diyanti, Anin, Widyarti dan Endang Tri. 2012. Analisis Pengaruh Faktor Internal dan Eksternal Terhadap Terjadinya Non-Performing Loan (Studi Kasus pada Bank Umum Konvensional yang Menyediakan Layanan Kredit Pemilikan Rumah Periode 2008-2011). Journal Of Management. Volume 1. Nomor 2. Tahun 2012. Halaman 290-299. Universitas Diponegoro. Semarang.

5. Kamalia Octaviyanty, Sunu Priyawan, dan Tri Ratnawati. 2013. Analisis Faktor Internal dan Eksternal Yang Mempengaruhi Kinerja Bank Umum di Indonesia Periode 2008-2011. DIE. Jurnal IImu Ekonomi \& Manajemen. Vol.9. No.1. Hal.47-55.

6. Kammilah. 2014. Analisis Pengaruh CAR, NPL, BOPO, NIM dan BI Rate Terhadap LDR Bank Negara

7. Maharani Ika Lestari. 2007. Analisis Kinerja Bank Devisa dan Bank Non Devisa dan Faktor-Faktor Yang Mempengaruhinya. Jurnal Proceeding PESAT (Psikologi, Ekonomi, Sastra, Arsitek \& Sipil). Vol.2. Fakultas Ekonomi. Universitas Gunadarma.

8. Nopirin. 2000. Ekonomi Moneter. BPFE. Yogyakarta.

9. Sesy Rizkiyanti Oktavia. 2010. Analisis Pengaruh BI Rate, Inflasi dan Jumlah Uang Beredar Terhadap Capital Adequay Ratio (CAR) dan Implikasinya Terhadap Penawaran Kredit Modal Kerja Pada Bank Umum Swasta Nasional (Periode 2004 sampai dengan 2009). Skripsi. Universitas Islam Negeri Syarif Hidayatullah. Jakarta.

10. Sukarno, Kartika Wahyu dan Muhamad Syaichu. 2006. Analisis Faktor-Faktor Yang Mempengaruhi Kinerja Bank Umum di Indonesia. Journal JSMO Vol. 3. No.2. Juli 2006. Universitas Diponegoro. Semarang. 